\title{
THE FIRE, THE BURGLARY AND THE PRAETORIAN EDICT DE NAUTIS, CAUPONIBUS ET STABULARIIS
}

\section{$1 \quad$ Introduction}

The travel and tourism industry is the world's largest industry. This industry is also seen as one of the priority growth areas for the South African economy. In South Africa travel and tourism activity is expected to grow at a rate of $4.8 \%$ per annum in real terms between 2007 and 2016. This will mean an increase in travel and tourism economic activity in South Africa from R198.1 billion in 2006 to R511.5 billion in 2016. Based on these figures it is estimated that the travel and tourism industry will contribute $9.3 \%$ of the South African Gross Domestic Product ("GDP") by 2016 (World Travel and Tourism Council 2006 The 2006 Travel and Tourism Economic Research 6).

One of the main benefits of the travel and tourism industry is its potential for attracting foreign currency (Vrancken "Introductory Perspectives on Travel Agency in South African Law" 2001 Obiter 492). Already, tourism is the fourth largest foreign exchange earner in South Africa (Department of Trade and Industry 1996 White Paper The Development and Promotion of Tourism in South Africa 14). Furthermore, the travel and tourism industry has major potential for generating employment. It is expected that by 2016 the travel and tourism industry will provide 1.5 million jobs (or one in every 11.6) in South Africa (World Travel and Tourism Council 2006 The 2006 Travel and Tourism Economic Research 6).

South Africa's travel and tourism industry has experienced significant growth in the last decade. This resulted in a substantial number of guest houses and bed-and-breakfast establishments opening their doors in every city, town and in between. This growth is evidenced, for example, in that South Africa is well on its way to reaching its target of attracting 10 million foreign visitors per year with a reported $7.6 \%$ increase in foreign visitors in the first five months of 2008 to a total of 3983061 (8 September 2008 Die Burger 3 ). With the rise in travel and tourism activity, it can be safely forecasted that there will be a rise in litigation revolving around the respective rights of tourists and tourist service providers. In a nascent travel and tourism law jurisprudence, each case decided in this regard ought to be carefully considered by both legal practitioners and the industry.

A matter came before the then Cape High Court during 2002, based on an action whose (continued) existence in South African law had been questioned more than eighty years earlier (see Davis $v$ Lockstone 1921 AD 154 159). The case was Gabriel v Enchanted Bed and Breakfast (2002 2 SA 597 CPD (hereinafter the "Gabriel case")). Just to confirm that this was not 
to be an isolated reliance upon an almost obsolete remedy, the Gabriel case was followed in 2005 by Roy $v$ Basson NO (2007 5 SA 84 CPD (hereinafter the "Roy case")). The legal remedy in question is the Praetorian edict de nautis, cauponibus et stabulariis. (Considering the fairly unique nature of the legal ground under consideration in these two cases it is somewhat surprising to note that the court in the Roy case did not refer to the Gabriel case at all).

Both these cases concern the liability of the proprietor of an inn in terms of the Praetorian edict de nautis, cauponibus et stabulariis and are therefore of particular relevance for the South African travel and tourism industry. It is therefore opportune to consider the Praetor's edict and its application anew.

\section{The Praetorian edict de nautis, cauponibus et stabulariis}

The edict de nautis, cauponibus et stabulariis, when introduced during the first century BC, was enacted essentially to make travelling possible. It had to serve, amongst others, as protection against the evil of unscrupulous innkeepers colluding with thieves to steal from the guests of the inn (Swart $v$ Shaw t/a Shaw Racing Stables 19961 SA 202 CPD 204I). Common to the professions covered by the edict was the fact that they were in a position which lent itself to abuse. The traveller who had to stay overnight at the inn had to deliver his property into the custody of the persons in charge of the inn and he had to depend on their good faith and honesty. In the case of damage or loss it was also very difficult to establish whose fault contributed to the loss (Zimmerman The Law of Obligations: Roman Foundations of the Civilian Tradition (1990) 516). Therefore, for policy reasons, the Praetor granted the edict de nautis, cauponibus et stabulariis, which was enforceable through the action de recepto. Initially the liability imposed by the edict was absolute, although, in time, exceptions were provided for reasons of equity (Zimmerman 515). The actio de recepto was an action granted in addition to other civil actions based on the underlying contracts, including lodging (Zimmerman 517; and Davis v Lockstone supra 163).

The Praetor framed his edict simply as "an action against sea carriers, innkeepers and stable-keepers if they fail to restore to any person any property of which they have undertaken the safe-keeping" (see Davis $v$ Lockstone supra 157; and Anderson Shipping (Pty) Ltd v Polysius (Pty) Ltd 19953 SA 42 AD 46C).

Voet (Commentary on the Pandects (Gane's translation) 492 767-768) describes the purpose of the action, and when it can be used, as follows:

"It lies for their making good all damage which has been sustained in whatever manner to the property received by theft, spoiling or otherwise, with the exception only of what clearly appears to have perished by inevitable loss or vis major, as by shipwreck or the outrage of pirates.

The case is not dissimilar where a house or stable has been broken into by burgling thieves and the property of travellers removed or horses taken away, provided that no negligence or fault of the keeper of the inn or stable-keeper is 
proved to have contributed. The reservation must be made that the proof of such chance happenings lies upon the sailors and inn-keepers.

Nor does it matter whether the damage to the property received has been caused by those whose services the person running the concern employed, or by passengers or travellers."

The position of the innkeeper, where his liability is governed by the Praetor's edict, arises as an inference from the nature of the contract which places him, the innkeeper, under an obligation to return the article or prove the reason why he has failed to do so (Stocks \& Stocks (Pty) Ltd $v T J$ Daly \& Sons (Pty) Ltd 19793 SA 754 (AD) 762B-D). The action that can be brought against nautis, cauponibus and stabulariis is therefore a special form of action which arises quasi ex contractu against mariners, innkeepers and stable-keepers who had received the property of anyone for safekeeping. Liability does not depend on negligence (see eg, O.K. Bazaars (1929) Ltd v Stern \& Ekermans 19762 SA 521 (C) 529C-D). So, in terms of the Praetorian edict liability for the damage or loss of property of the traveller will follow where the innkeeper had received the property of the traveller, unless the liability has been specifically excluded by the parties (see Zimmerman 520; and Van der Bijl "B \& B Establishments, Hotels and the Praetorian edictum de nautis cauponibus et stabulariis: cessante ratione legis cessat lex ipsa?" 2006123 SALJ 571). The traveller does not have to prove negligence and therefore the innkeeper is forced to rely on the recognized exceptions in order to escape liability.

The edict has been received into and applies in South African law (see eg, Davis $v$ Lockstone supra 159; and Swart $v$ Shaw t/a Shaw Racing Stables 19961 SA 202 (CPD) 205A). The Appellate Division, as it then was, in Stocks \& Stocks (Pty) Ltd v T J Daly \& Sons (Pty) Ltd supra 761F-H summarized the effect of the edict in the following words:

\footnotetext{
"The general effect of the Edict is to impose upon seamen, innkeepers and stable-keepers an absolute liability for all loss of or damage to goods given into their custody, unless the loss or damage falls within one or other of certain acknowledged exceptions, viz casus fortuitus, damnum fatale or vis major, negligence of the consignor or inherent vice or latent defect in the goods themselves."
}

What exactly constitutes vis major, casus fortuitus and damnum fatale can often be quite difficult to determine. Vis major, or superior force, is some force or power which cannot be resisted or controlled by the ordinary individual and the meaning of the term has been extended to include not only acts of nature, vis divina or acts of God, but also acts of man (Du Bois (ed) Wille's Principles of South African Law 9ed (2007) 849-850). Examples of vis major would include "fires arising from lightning or from neighbouring houses, in shipwreck and in the violence of robbers" (see Voet $492767 \mathrm{ngg}$ and 768). Casus fortuitus (or inevitable accident) is a species of vis major and it imports an element of exceptional, extraordinary or unforeseen circumstances, and which human foresight cannot be expected to anticipate or, if it can be foreseen, then it cannot be avoided by the taking of reasonable care (Du Bois 850). Damnum fatale means unavoidable loss, 
which is damage due to inevitable accident or to an act of God (Hiemstra and Gonin Trilingual Legal Dictionary 2ed (1986) 183).

Considering the aforegoing it is little wonder that the strict distinctions between vis major, casus fortuitus and damnum fatale have become blurred and it is now accepted that an occurrence which is unforeseen, unexpected and irresistible and which human foresight cannot guard against, such as burglary with violence and unavoidable accident, can be raised as a special defence by the innkeeper (Gabriel $v$ Enchanted Bed \& Breakfast supra 599l600A; Du Bois 974; and Moss "Carriage" in Joubert (ed) LAWSA Vol 2 2ed (2003) Part 1 par 607).

An important consequence of the imposition of strict liability is the fact that the onus rests on the innkeeper to establish that he is not liable. The innkeeper cannot escape liability by showing that he acted with all due diligence or that the loss was not caused by his negligence (Stocks \& Stocks (Pty) Ltd v T J Daly \& Sons (Pty) Ltd supra 761H). To avoid liability, the innkeeper must prove, as a special defence, that the cause of the damage resulted from circumstances that fall within one of the exceptions (Voet 492 768; Moss par 607; see also Roy v Basson supra 86B-C; and Stocks \& Stocks (Pty) Ltd v T J Daly \& Sons (Pty) Ltd supra 761H).

However, where it is proved (and it is the traveller that will bear the onus in this instance) that the innkeeper contributed through his negligence to the damage and loss the guest had suffered, the protection of the exceptions will be nullified. The traveller may show that the innkeeper's negligence exposed the goods to an occurrence which would normally constitute an exception, such as vis major. The act of the innkeeper therefore constitutes a novus actus interveniens (Moss par 607; Beckerling and Douvelos "Tourism" in Joubert (ed) LAWSA Vol 28 first re-issue (2003) par 42; and see also Voet 4 92 767-768).

Where the damage or loss resulted from the negligence of the traveller, the innkeeper will be absolved from liability (see Moss par 607; and Beckerling and Douvelos par 42).

Of relevance also is that liability for property received is not limited only to property handed over for safekeeping to the innkeeper, but also property not expressly accepted by or entrusted to the innkeeper (see Beckerling and Douvelos par 42). The court in Davis v Lockstone (supra 161) stated that

"[t]o hold that $\ldots$ the inn keeper would not be liable for the loss of luggage which had not been specially entrusted to him for safe keeping, would make the law of but little effect, seeing that a guest in an hotel needs his luggage in his room, and consequently could not hand it over to the proprietor for safe keeping."

The attention will now turn to the Gabriel and Roy cases respectively. 


\section{The Gabriel case}

\section{Facts of the case}

The plaintiffs, during a visit to South Africa from the USA, stayed at the defendant, who operated a bed-and-breakfast establishment in Sea Point, Cape Town. One night, whilst the plaintiffs were sleeping, a burglar gained access to their room and stole their personal belongings to the value of R252 000 (597l-599F)! The burglary was not accompanied by violence (599I-600A). The court furthermore found that access was gained by the burglar to the room via a small window in the en-suite bathroom (604F). This window opening was not secured by burglar proofing at the time but on opening it permitted a gap of $18 \mathrm{~cm}(598 \mathrm{E}-\mathrm{F})$.

The plaintiffs relied on the Praetorian edict de nautis, cauponibus et stabulariis (599F). To this the defendant raised a number of defences, particularly that the loss was unforeseen, unexpected and irresistible; that the defendant was exempt from liability; that plaintiffs' negligence caused the loss, and that the defendant was entitled to an apportionment of damages $(599 \mathrm{H}-\mathrm{I})$.

\section{Decision and reasoning of the court}

The court (per Cleaver $\mathrm{J}$ ) found that on the facts a prima facie case was established for holding the defendant liable in terms of the Praetor's edict (599F). The court then had to deal with the defences raised by the defendant.

The court made short work of the defence that the loss was caused by unforeseen, unexpected and irresistible circumstances, finding that, in the light of the prevailing circumstances, this defence could not succeed $600 \mathrm{~A}$ D). The prevailing circumstances referred to two facts: thefts from houses in the area were common at the time, and break-ins were invariably not accompanied by violence.

The defence that the defendant was exempted from liability because of notices on the premises excluding liability for any losses sustained by any cause was also rejected by the court. It was found that the plaintiffs were unaware of these notices and could therefore never have agreed thereto (600E-601B).

The third defence raised the question of the negligence of the plaintiffs. This aspect received the most attention, with the court concluding that the plaintiffs were not negligent (605D-E).

Lastly, the court rejected the argument that there was contributory negligence on the part of the plaintiffs. The court pointed out that the defendant's liability flowed from the Praetor's edict and not from negligence. Therefore it was not correct to speak of contributory negligence and, in any event, there was no negligence on the part of the plaintiffs. However, the 
court found that it was the defendant who was negligent in failing to take adequate measures to prevent the foreseen danger $(605 \mathrm{~F}-\mathrm{H})$.

Judgment was granted in favour of the plaintiffs (605I-J).

\section{The Roy case}

\section{Facts of the case}

The Appellant was a tourist from France. She had stayed at the Wedge Farm Inn, Stellenbosch and, whilst travelling to other parts of South Africa, had stored some of her possessions at the inn (84E-F). Subsequently a fire had broken out in a plantation near the inn, from which fire burning objects driven on by a strong wind had set fire to the inn. The possessions of the tourist stored at the inn were destroyed. She sought to recover her damages from the estate of the owner (now deceased) of the inn, which claim was refused by the Magistrate's Court. The claim for damages was based on the Praetorian edict de nautis, cauponibus et stabulariis; in the alternative the claim was based on the negligence of the Wedge Farm Inn in that it had not, amongst others, taken proper precautions or preventative measures to avoid the damage (86A-B).

The Respondent pleaded "that the fire and subsequent damage were caused by damnum fatale, alternatively vis major, as an occurrence which was unforeseen, unexpected and irresistible and that therefore the Praetor's edict was not applicable" (86C). Negligence was also denied, and as further alternative it was claimed that there was a tacit or implied agreement that goods were stored at the owner's risk and that the appellant had waived the liability (of the innkeeper) when she came to stay at the inn (86D).

\section{Decision and reasoning of the court}

The court (per Selikowitz J, with Traverso DJP concurring) explained that the South African law relating to innkeepers imposes strict liability on the innkeeper for damage to the property of a guest who brings it into the inn, unless the innkeeper can prove that the damage was a result of major casus fortuitus or damnum fatale (86E-F). A defendant therefore bears the onus of proof where the edict is relied upon as the basis for a claim (86B).

On the facts the court found that "the flying through the air of the flaming object was not a matter that could be resisted, nor indeed avoided, and that it was as a result of vis major or casus fortuitus that the particular roof was ignited on the day in question" (87F).

As far as the question of the lex Aquilia and particularly the issue of negligence are concerned, the court found on the evidence that the Respondent in no way behaved unreasonably so as to provide the grounds for a claim based on negligence (88F-G). The issue of a contractual exclusion of liability was not pursued in light of all the documentation of the Wedge Farm Inn having been destroyed in the fire $(88 \mathrm{G}-\mathrm{H})$. 
The appeal was therefore dismissed (88I).

\section{Discussion}

In the following discussion, which takes place against the background of the cases set out above, two aspects will be addressed. Firstly, the question will be considered why the plaintiff in the Roy case did not place reliance on the contract of depositum as opposed to the Praetorian edict. Secondly, an attempt will be made at providing a conceptual framework for application of the Praetorian edict with particular reference to the situation where the damage or loss occurred as a result of theft and burglary.

Depositum can be defined as "a contract whereby one person delivers a thing to another for the purpose of safe custody and the latter gratuitously or for reward undertakes to take care of the thing and restore it on demand." (Bester "Deposit" in Joubert (ed) LAWSA Vol 8 2ed (2005) Part 1 par 174). In order for such a contract to come into being, there must be an undertaking to retain and have charge of something, and not merely a passive acquiescence that an object may be left somewhere (Bester par 174). In Biden $v$ Frank (1886 OFS 16 18) the court also expressed the view that for a person to be liable in respect of another as depositarius there has to be an express agreement, or facts constituting something similar, from which a relationship of depositum can be concluded. Although the facts of the Roy case are silent on this aspect, it is very difficult to accept that in this particular scenario there was no explicit agreement of depositing the property of the tourist with the inn, making the application of the Praetor's edict in casu even less understandable.

A contract of depositum requires of the depositarius to keep the object deposited in his custody; to take proper care of the object so entrusted to him, and to restore the thing unimpaired to the depositor (see Bester par 177; and Swart $v$ Shaw Racing Stables supra 208C). However, the depositarius does not have a duty of special care in respect of the object deposited. What is required is the same care and vigilance that the depositarius would apply in respect of his own property (see Frank $v$ Biden (supra 20).

The depositary, if unable to restore the object left for safe-keeping in an undamaged condition, however, has the onus of proving that the damage was not a result of his negligence (see Bester par 179). In Stocks \& Stocks $v$ T J Daly \& Sons (Pty) Ltd (supra 762A) the court stated that the depositary "is under a duty to exercise reasonable care in regard to the goods entrusted to him for conveyance and ..., in the event of the goods being damaged or destroyed, is liable in damages to the owner thereof unless he can show that the damage or destruction occurred without culpa or dolus on his part". C):

The Appellate Division, as it then was, continued as follows (supra 762B-

"The position of a contracting party whose liability is governed by the provisions of the Praetor's Edict and the position of a depositary or bailee for reward is similar in that in each case the onus which lies on him in regard to 
loss of or damage to the goods entrusted to his custody 'arises as an inference from the nature of the contract which places him under an obligation to return the article or prove the reason why he has failed to do so' ...; the only real difference being that in the case of the party subject to the Praetor's Edict the grounds upon which he can escape liability are substantially more circumscribed than in the case of the depositary or bailee for reward."

The answer as to why reliance was not placed on a contract of depositum probably lies in the above paragraph - escaping liability is more difficult ("substantially more circumscribed") for the innkeeper subject to the Praetor's Edict than the depositary.

But why did the defendant (respondent) not raise the fact that the Praetor's edict could not be applied to the facts because at the relevant time the plaintiff/appellant was no longer a guest at the inn? The fact that the guest had left the inn on further travels had as a necessary consequence the exclusion of the Praetor's edict from application to the case. In Frank $v$ Biden (supra 18) the court confirmed that the liability of the innkeeper in terms of the edict did not extend beyond the departure of the traveller. It is therefore submitted that a more appropriate basis for the claim should have been the contract of depositum.

The attention will now turn to the second aspect mentioned. The test for excluding the strict liability imposed under the edict is whether the loss or damage to the property of the guest was the result of an occurrence that was unforeseen and/or unexpected and/or irresistible and/or something that human foresight could not guard against. Once it is established that the occurrence which caused the damage or loss was indeed an occurrence which could not be foreseen, expected, resisted or which human foresight could not guard against, and the onus is on the innkeeper to do so, liability of the innkeeper is excluded. The establishment of an exception can be undone, however, by the traveller showing that the innkeeper was negligent in exposing the goods to the occurrence which would normally qualify as an exception.

In the Roy case the court held that, in determining liability under the edict, it must consider the circumstances relating to the particular event (in this case the particular fire). In the context of this case it was not sufficient to say that there have been a number of fires in the area and therefore this particular fire, and resultant damage, should have been foreseen (87B). The correct approach is to consider the particular circumstances under which the loss or damage occurred to determine whether those were circumstances that resulted from some power or agency which could not be resisted or controlled by the ordinary individual. From the facts of the case it was clear that the fire and resultant loss initially were not foreseeable (as the firemen on the scene advised against evacuation of the inn (88E-F)) and, secondly, the spreading of the fire to the inn could not be resisted $(87 \mathrm{~F})$.

The issue of theft, burglary and robbery present particular difficulties. Theft is not considered to be "inevitable loss" and is distinguished from loss caused by "burgling thieves" and robbery (Voet 492767 n9g). However, burglary in this context must not be given a strict technical meaning of 
housebreaking but should be understood in the sense of breaking into a house (or inn or hotel) by force (Davis $v$ Lockstone supra 161 and 166). Theft perpetrated by the mere opening of a door or window (which could technically constitute housebreaking or burglary) would therefore not necessarily bring the loss within the understanding of an "inevitable loss" for purposes of excluding the liability of the innkeeper. The innkeeper will have to show that the occurrence was indeed an occurrence which could not be foreseen, expected, resisted or which human foresight could not guard against. The innkeeper will have to show that, where the occurrence could be reasonably foreseen, he had taken reasonable measures to prevent it. The more violence is used in perpetrating the damage or loss the more unforeseen, unexpected and/or irresistible the loss is. The less violence is used the more difficult it may be for the innkeeper to establish that the loss or damage was indeed unforeseen, unexpected, irresistible, or that human foresight could not have guarded against the event.

Zimmerman (521) points out that "[t]here have always been reasons for the receptum, ..., most notably those deriving from the fact that the customer and his property are exposed to dangers emanating from a sphere which only the other party is able to organize and control". It is exactly for this reason, and the difficulty that the traveller will have in proving fault, that the Praetorian edict must still apply by imposing strict liability on the innkeeper. Without the edict the traveller will be in an untenable position in cases of housebreaking without violence. The least a traveller could expect from the innkeeper is that the latter takes reasonable precautions in safeguarding the property of the traveller whilst a guest at the inn.

In the Gabrie/ case the questions arise whether, firstly, the event of a theft or burglary happening was foreseeable and, if so, whether it could be resisted by taking reasonable precautionary measures. Considering the context of the event it is relevant that there were numerous break-ins in the area and that these break-ins were not accompanied by violence. The potential for loss to guests had to be foreseen and, in turn, had to be guarded against by taking reasonable precautions.

Could the taking of reasonable measures have prevented the loss? By securing the window this particular burglary and resultant loss could have been prevented. As it is the innkeeper that is subject to the imposition of strict liability he should have ensured that the window was closed or secured by having had burglar proofing installed. Had the window been secured and had that obstacle been overcome with violence then, in all likelihood, the innkeeper would have escaped liability as the use of violence could not have been foreseen. It is the lack of reasonable precautions to guard against a foreseeable occurrence that founded liability on the part of the inn-keeper.

It is submitted that the position regarding the application of the Praetorian edict in relation to theft (which is understood to include non-violent housebreaking) can be set out in the following terms: As a point of departure loss or damage as a result of theft results in the innkeeper being liable. This liability is not depended upon the negligence of the innkeeper and is 
imposed for policy reasons. (This does not mean that the presence of negligence will be irrelevant in all situations as has already been indicated).

If the loss or damage is the result of theft that was not foreseeable then it means that the occurrence falls within the ambit of what can be described as an exception to the application of the edict. There is then no liability. The innkeeper must establish this exception.

Where the occurrence is foreseen or is reasonably foreseeable, it requires that consideration be given to whether the innkeeper took reasonable measures to prevent the occurrence or not. If reasonable measures were taken to prevent the occurrence but it still occurred, then there is no liability as the overcoming of the reasonable preventative measures will qualify as an exception (for being eg, irresistible). Again the innkeeper will bear the onus to prove that the occurrence is an exception (because it could not be resisted despite reasonable measures having been taken). Where the occurrence is foreseen or reasonably foreseeable and the innkeeper does not take reasonable measures to prevent the occurrence then the innkeeper will be liable for the loss based on his negligence (see Voet 429 768).

\section{Conclusion}

The current day B \& B establishment or lodge is generally a far cry from the ignoble innkeeper of two thousand years ago who collaborated with thieves to steal from the guests. Yet, the traveller and his property are exposed to dangers emanating from a sphere which only the innkeeper is able to manage and control. This, and the difficulty that the traveller has to face in proving fault, still provide a compelling rationale for the Praetorian edict. The crucial role that is played by the travel and tourism industry in the South African economy requires that travellers and tourists still be afforded the protection of the Praetorian edict de nautis, cauponibus et stabulariis. There is also something eminently comforting and consistent about an action more than two thousand years old, still guiding us in resolving disputes.

Mark Tait and Patrick Vrancken Nelson Mandela Metropolitan University, Port Elizabeth 